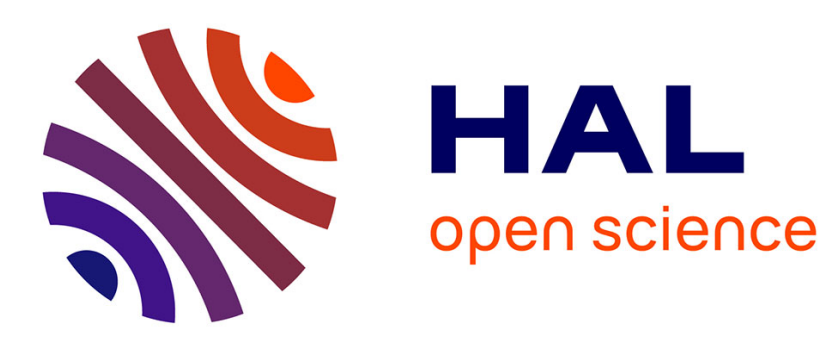

\title{
Spatial Persistence of Water Chemistry Patterns across Flow Conditions in a Mesoscale Agricultural Catchment
} Sen Gu, A. Casquin, Rémi Dupas, Benjamin W W Abbott, Patrice Petitjean, Patrick Durand, G. Gruau

\section{- To cite this version:}

Sen Gu, A. Casquin, Rémi Dupas, Benjamin W W Abbott, Patrice Petitjean, et al.. Spatial Persistence of Water Chemistry Patterns across Flow Conditions in a Mesoscale Agricultural Catchment. Water Resources Research, 2021, 57 (7), pp.e2020WR029053. 10.1029/2020WR029053 . insu-03283695

\section{HAL Id: insu-03283695}

https://hal-insu.archives-ouvertes.fr/insu-03283695

Submitted on 12 Jul 2021

HAL is a multi-disciplinary open access archive for the deposit and dissemination of scientific research documents, whether they are published or not. The documents may come from teaching and research institutions in France or abroad, or from public or private research centers.
L'archive ouverte pluridisciplinaire HAL, est destinée au dépôt et à la diffusion de documents scientifiques de niveau recherche, publiés ou non, émanant des établissements d'enseignement et de recherche français ou étrangers, des laboratoires publics ou privés. 


\title{
Spatial Persistence of Water Chemistry Patterns across Flow Conditions in a Mesoscale Agricultural Catchment
}

\author{
S. Gu ${ }^{1,2 *}$, A. Casquin ${ }^{3 \dagger}$, R. Dupas ${ }^{3}$, B. W. Abbott ${ }^{4}$, P. Petitjean ${ }^{2}$, P. Durand ${ }^{3}$, G. Gruau ${ }^{2}$ \\ ${ }^{1}$ Institute of Hydrobiology, Chinese Academy of Sciences, Wuhan 430072, China, ${ }^{2} \mathrm{CNRS}$, \\ OSUR, Géosciences Rennes, UMR 6118, Univ. Rennes, Rennes F-35000, France, ${ }^{3}$ UMR SAS, \\ INRAE, Institut Agro, Rennes F-35000, France, ${ }^{4}$ Brigham Young University, Department of \\ Plant and Wildlife Sciences, Provo, UT 84602,USA \\ *Corresponding author: Sen Gu (gusen@ihb.ac.cn) \\ $\dagger$ Co-first author
}

\section{Key Points:}

- We found high spatial persistence of water chemistry, despite high spatiotemporal variability in water chemistry

- Spatial persistence of water chemistry is primarily determined by the ratio between spatial and temporal variability

- A single synoptic sampling during the high-flow season allows efficient identification of source and sink subcatchments

This article has been accepted for publication and undergone full peer review but has not been through the copyediting, typesetting, pagination and proofreading process, which may lead to differences between this version and the Version of Record. Please cite this article as doi: 10.1029/2020WR029053.

This article is protected by copyright. All rights reserved. 


\begin{abstract}
Protecting water quality at catchment scales is complicated by the high spatiotemporal variability in water chemistry. Consequently, determining pollutant sources requires costly monitoring strategies to diagnose causes and guide management solutions. However, recent studies have shown that spatial patterns in water chemistry can be persistent at catchment scales, potentially allowing identification of pollution sources and sinks with just a few sampling campaigns. Here, we tested a new method to quantify spatial persistence (SP) of water chemistry patterns with data from synoptic samplings in 22 headwater subcatchments within a $375 \mathrm{~km}^{2}$ catchment in western France (March 2018 - July 2019). This new method to quantify SP reduces dependence on longterm metrics such as flow-weighted concentrations, which are usually uncertain or unavailable. We applied the method to 16 ecologically relevant water quality parameters, including soluble reactive phosphorus, nitrate, and dissolved organic carbon. The results showed an average SP of 0.68 among parameters during the study period. For most parameters, SP was higher during the high-flow winter period but lower and more variable during the low-flow summer period. We found that the SP ultimately depended on the ratio between the temporal and spatial coefficients of variation (variance explained: 70\%) rather than the temporal synchrony among subcatchments (variance explained: 4\%). These results demonstrate that in these temperate catchments, synoptic sampling during the high-flow winter period allows efficient identification of source and sink subcatchments, while more frequent samplings are needed to characterize ecological conditions at low flow.
\end{abstract}

\title{
1 Introduction
}

Despite decades of research and changes to management, degrading water quality is still one of the most urgent issues for human society in the $21^{\text {st }}$ century (Vörösmarty et al., 2010; Sutton et al., 2011; UNICEF, 2019). Water pollution causes approximately two million deaths each year, and excess nutrients cause eutrophication in more than $50 \%$ of global freshwater and estuarine water bodies (Conley et al., 2009; Matthews, 2014; Le Moal et al., 2018). Human activities, such as agriculture, urbanization, and disturbance of natural ecosystems can deliver excess nutrients to aquatic ecosystems, triggering eutrophication (Withers et al., 2014a; Jenny et al., 2016; Van Meter et al., 2017; Bol et al., 2018). The harmful algae blooms and dead zones associated with eutrophication degrade human health, water supply, and recreational uses (Conley et al., 2009; Ward et al., 2018). These anthropogenic pressures on aquatic ecosystems are predicted to intensify through the middle of the century because of population growth, increasing food demand (particularly meat and dairy), and climate change (Seitzinger et al., 2010; Ibarrola-Rivas et al., 2017; Sinha et al., 2019; Frei et al., 2020). In response, national and international agencies worldwide have made substantial investments to establish water quality monitoring networks to identify pollution sources, and implement management measures that reduce pollutant losses from land to water at field to catchment scales (Hering et al., 2010; Skeffington et al., 2015; Wurtsbaugh et al., 2019).

Water flow and chemistry are highly variable in space and time, creating a substantial challenge to representative monitoring and robust prediction of water quality in complex freshwater landscapes (Guo et al., 2018; Lintern, et al., 2018; Alilou et al., 2019; Mentzafou et al., 2019). This inability to reliably measure or infer water quality has contributed to mixed results of water quality interventions (Jenny et al., 2016; Abbott et al., 2018a; Kleinman et al., 2019). Current monitoring approaches face two competing challenges: the headwater conundrum

This article is protected by copyright. All rights reserved. 
and the sampling frequency conundrum (Johnes, 2007; Cassidy and Jordan, 2011; Lloyd et al., 2015; Skeffington et al., 2015; Abbott et al., 2018a).

The headwater conundrum refers to the fact that current monitoring networks are mostly implemented in medium-to-large rivers, while most of the nutrient fluxes enter the watercourses from headwater catchments $\left(<50 \mathrm{~km}^{2}\right)$ (Skeffington et al., 2015; Helton et al., 2018). Unlike the catchments larger than $100 \mathrm{~km}^{2}$, where riverine nutrient fluxes are strongly associated with the percentage of agricultural land use (Jordan et al., 1997; Strayer et al., 2003), nutrient fluxes in smaller catchments vary widely despite similar land use (Lefebvre et al., 2007; Schilling et al., 2013; Abbott et al., 2018a; Bol et al., 2018; Casquin et al., 2020). This relationship breakdown between nutrient flux and catchment characteristics emphasizes the need to better understand the nutrient sources, sinks, and pathways in headwater catchments, in which more than $90 \%$ of global stream length occurs (Bishop et al., 2008; Downing, 2012). At the same time, the sheer number of headwater streams makes continuous monitoring impractical, limiting the identification of nutrient sources at the scale where preventive actions could be most effective and tractable (Thomas et al., 2016; Abbott et al., 2018a; Dupas et al., 2018).

The sampling frequency conundrum results from temporal variability in riverine water chemistry on event, seasonal, and interannual timescales (Abbott et al., 2018a; Zarnetske et al., 2018). A significant share of the annual flux can be transported during just a few storm events, especially for phosphorus (P) and carbon (C; Johnes, 2007; Cassidy and Jordan, 2011; Kirchner and Neal, 2013; Lloyd et al., 2015; Shogren et al., 2020). Though there are fewer observations from small streams due to the headwater conundrum, variability in water chemistry may be even greater in "flashy" headwaters compared to mesoscale rivers (Abbott et al., 2018a). To reveal nutrient dynamics and identify their potential sources within catchments, current monitoring networks conduct temporally intensive or sometimes nearly continuous sampling at selected locations (Bowes et al., 2015; Rode et al., 2016; Bieroza et al., 2018; Fovet et al., 2018; Yang et al., 2018). However, high-frequency sensors are often too expensive to be widely deployed, especially in developing countries where degraded water quality is most directly impacting public health (Crocker and Bartram, 2014; Landrigan et al., 2017).

This vision is nevertheless changing. Informed by landscape ecology and catchment hydrology, recent studies (Abbott et al., 2018a; Dupas et al., 2019; Shogren et al., 2019; Frei et al., 2020; Weller and Jordon, 2020) quantified the spatiotemporal variability of water chemistry in headwater stream networks by infrequent synoptic sampling and found that the spatial patterns of the stream water chemistry were unexpectedly persistent on seasonal to decadal timescales (Abbott et al., 2018a; Dupas et al., 2019; Shogren et al., 2019). If this spatial persistence (SP) of water chemistry patterns through time is widespread, it could resolve the monitoring conundrums described above by allowing reliable characterization of nutrient concentrations or even fluxes with infrequent synoptic sampling. SP results from the interaction between the spatial variability of water chemistry among sites and the degree and synchronicity of temporal variations of water chemistry at each site. On the French national scale, for example, a single sampling was found to capture $88 \%$ of the spatial variability of $\mathrm{NO}_{3}{ }^{-}$across ecoregions with different climate and landuse conditions (Dupas et al., 2019).

While SP of water chemistry could provide a shortcut to effective water-quality diagnoses, the current method to calculate SP requires more data than is available in many areas of the world (Bogena et al., 2018; Abbott et al., 2018a). SP is typically calculated from Spearman's rank correlations between concentrations of individual sampling dates and long-term

This article is protected by copyright. All rights reserved. 
concentration metrics such as the flow-weighted mean concentration, flux, or various quantiles (Abbott et al., 2018a; Dupas et al., 2019). For catchments with only infrequent observations, the calculations of these long-term metrics introduce substantial uncertainty. In this context, we developed a new method to calculate the SP in water chemistry, by pair-wise Spearman rank correlations among sampling dates. If robust, this approach could lead to more efficient and widely applicable monitoring approaches for quantifying and regulating water quality across spatial scales. We demonstrated this new method in an intensively cultivated mesoscale catchment (Yvel catchment, $375 \mathrm{~km}^{2}$ ) located in Brittany (western France), where we conducted repeated synoptic sampling of headwater subcatchments across flow conditions and seasons, with the main objectives to assess the seasonal variations in SP of water chemistry and to verify its controlling factors.

\section{Materials and Methods}

\subsection{Site description and hydrochemical monitoring}

The Yvel catchment $\left(375 \mathrm{~km}^{2}\right)$ is drained by a $5^{\text {th }}$ order river that discharges into the "Lac au Duc", a 3 million $\mathrm{m}^{3}$ recreational and drinking water reservoir suffering from cyanobacteria blooms since the 1970s (ODEM, 2012). The mean discharge at the outlet of the catchment ranges from $0.52 \mathrm{~L} \mathrm{~s}^{-1} \mathrm{~km}^{-2}$ in August to $18.67 \mathrm{~L} \mathrm{~s}^{-1} \mathrm{~km}^{-2}$ in February. The climate is temperate oceanic with the average temperature ranging from $7.1^{\circ} \mathrm{C}$ in November and March to $17.1^{\circ} \mathrm{C}$ in July and September, and a mean annual precipitation averaging $777 \mathrm{~mm}$ of which approximately $50 \%$ falls between November and March (1998-2017). The catchment has shallow soils, with $70 \%$ of the catchment having soils less than $70 \mathrm{~cm}$ deep and the remaining $30 \%$ less than $1 \mathrm{~m}$. Soils are luvisols in the north and brown soils in the rest of the catchment. The land use consists of $54 \%$ arable fields (maize and winter cereals), $21 \%$ grassland (mostly leys in rotation), $18 \%$ forest, and 6\% urban area. A more detailed catchment description can be found in Casquin et al., (2020).

We conducted repeated synoptic sampling from March 2018 to July 2019 approximately every 2 weeks (31 sampling dates in total) in 22 selected headwater subcatchments within the Yvel catchment (Figure 1). The 31 sampling dates covered all ten deciles of long-term discharge (1998-2017), i.e. they captured the full range of water flow in the Yvel catchment. The 22 subcatchments were selected based on stream order (1-3), size $\left(0.8-14.2 \mathrm{~km}^{2}\right)$, accessibility, and representativeness of soil type/land use/topography in the whole Yvel catchment. These 22 subcatchments represented 33.5\% of the whole catchment area (See Table S1 for the detailed land use, soil properties, and topographic information).

Water samples were collected with a PVC cup equipped with a long aluminum handle during high flows and with $50 \mathrm{ml}$ syringes when the water level was low. We were careful to avoid artificial resuspension of river sediments during sampling. We selected sampling locations that were immediately upstream of roads and bridges and allowed access to the sites. We measured 16 common and ecologically relevant water quality parameters for all water samples, including different forms of $\mathrm{P}$ (soluble reactive phosphorus [SRP], total dissolved phosphorus [TDP], total phosphorus [TP], and particulate phosphorus [PP]), C species (dissolved organic carbon [DOC], dissolved inorganic carbon [DIC]), anions $\left(\mathrm{NO}_{3}^{-}, \mathrm{NO}_{2}^{-}, \mathrm{F}^{-}, \mathrm{Br}^{-}, \mathrm{Cl}^{-}, \mathrm{SO}_{4}{ }^{2-}\right)$, physicochemical parameters measured with in-situ sensors ( $\mathrm{pH}$, dissolved $\mathrm{O}_{2}$, conductivity), and specific ultraviolet absorbance at $254 \mathrm{~nm}\left(\mathrm{SUVA}_{254}\right)$. All water samples were filtered on site

This article is protected by copyright. All rights reserved. 
after sampling, using cellulose acetate filters of $0.45 \mu \mathrm{m}$ pore size for SRP and TDP, and 0.20 $\mu \mathrm{m}$ pore size for $\mathrm{C}$, anions, and $\mathrm{SUVA}_{254}$ analyses, respectively. All filters were rinsed with 20 $\mathrm{ml}$ deionized water in the laboratory prior to use. An unfiltered subsample was collected for the analysis of TP. All samples were transported to the laboratory in a cooler and then refrigerated at $4^{\circ} \mathrm{C}$ until analysis within 1 week.

SRP was determined colorimetrically by direct reaction with ammonium molybdate (Murphy and Riley, 1962). The same method was used for TDP and TP but after digestion in acidic potassium persulfate. The precision of SRP, TDP, and TP measurements was $\pm 4, \pm 13, \pm 13$ $\mu \mathrm{g}^{-1}$, respectively. PP was calculated as TP minus TDP. DOC and DIC were analyzed with a total organic C analyzer (Shimadzu TOC-5050A; precision $\pm 5 \%$ ). SUVA 254 values were calculated by dividing ultraviolet absorbance at $254 \mathrm{~nm}$ with the DOC concentration. Ultraviolet absorbance was measured with a Lambda 25 (PerkinElmer) spectrophotometer using deionized water as a blank. Anions were quantified by ion chromatography (DionexTMDX 100; precision $\pm 2.5 \%$ ). Dissolved $\mathrm{O}_{2}, \mathrm{pH}$, and conductivity were measured in situ by portable multiparameter probes (Multi 3430 SET F). Concentrations for most parameters were above their quantification limits during most sampling dates (Figure S1), except for $\mathrm{NO}_{2}{ }^{-}$, whose concentrations were below the detection limit in approximately $25 \%$ of all nitrite samples. We assigned the value of half the limit of nitrite quantification $\left(0.0076 \mathrm{mg} \mathrm{l}^{-1}\right.$ in $\left.\mathrm{N}\right)$ for those samples.

\subsection{Estimation of water quality metrics}

The SP metric indicates the persistence of the water chemistry pattern (i.e. relative spatial differences) through time. It is commonly calculated with the Spearman's rank correlations between concentrations of individual sampling dates and long-term concentration metrics, which can introduce uncertainty in the estimation (Abbott et al., 2018a; Cassidy and Jordan, 2011; Dupas et al., 2019). To reduce the dependence on uncertain and often unavailable estimates of long-term metrics, we quantified SP by comparing the concentration rank of an individual sampling date with the concentration ranks of the other 30 sampling dates using Spearman's rank correlation and then used the median value of the 30 correlation coefficients as the SP of this individual sampling date, as follows:

$$
\mathrm{SP}_{\text {pairs }}=\operatorname{median}\left\{\operatorname{rcorr}\left(C_{t}, C_{t_{i} \neq t}\right)\right\}
$$

where the $\mathrm{SP}_{\text {pairs }}$ at an individual sampling date $(\mathrm{t})$ is the median value of the Spearman's rank correlation coefficient (rcorr) between the concentrations of subcatchments at this sampling date $\left(\mathrm{C}_{\mathrm{t}}\right)$ and the concentrations of the other 30 sampling dates $\left(C_{t_{i} \neq t}\right)$.

An SP value of 1 indicates that the sampling date perfectly predicts the relative water chemistry across all sites for at least half of the whole monitoring period. A detailed time series of SP provides useful information about when synoptic sampling better represents the annual or long-term water quality at the catchment scale.

At a mathematical level, three non-exclusive factors contribute to the SP of water chemistry: the spatial and temporal variance of water chemistry and the temporal synchrony of water chemistry among subcatchments (Figure 2). We quantified the spatial variability of water chemistry as the coefficient of variation $(\mathrm{CV})$ of water chemistry at each date (hereafter referred to as Spatial CV):

$$
\text { Spatial CV }=\frac{\sigma_{t}}{\mu_{t}}
$$

This article is protected by copyright. All rights reserved. 
where $\mathrm{t}$ is the sampling date, $\sigma$ the standard deviation, and $\mu$ the mean of concentrations at this date for all the sites.

We quantified the temporal variability of water chemistry as the CV of water chemistry at each site (hereafter referred to as Temporal CV):

$$
\text { Temporal CV }=\frac{\sigma_{s}}{\mu_{s}}
$$

where $\mathrm{s}$ is the sampling site, $\sigma$ the standard deviation, and $\mu$ the mean of concentrations at this site for all the dates. The temporal synchrony quantifies the similarity of subcatchments in response to changes in factors controlling stream water chemistry. We quantified the temporal synchrony among subcatchments for each parameter at each site with Spearman's rank correlations between time series from pairs of subcatchments $\left(22^{\wedge} 2\right.$ pairs $)$ :

$$
\text { Temporal synchrony }=\operatorname{median}\left\{\operatorname{rcorr}\left(C_{s}, C_{s_{i}}\right)\right\}
$$

where temporal synchrony of an individual site (s) is the median of the Spearman's rank correlation (rcorr) coefficients between set of concentrations at this site and all the 22 subcatchments $\left(\mathrm{s}_{\mathrm{i}}\right)$.

For a given water quality parameter, spatial $\mathrm{CV}$ and $\mathrm{SP}_{\text {pairs }}$ were determined for each date while temporal CV and synchrony were determined for each site (Figure 2 and Eqs. 1-4).

High SP of water chemistry could result from a much higher spatial CV among multiple sampling sites relative to the temporal CV of those sites (Hammond and Kolasa, 2014; McGuire et al., 2014; Botter et al., 2020). In this case, the curves representing time-series of concentrations cross less and the relative rank of concentrations would be preserved through time (Figure 2). High SP could also derive from high temporal synchrony among sampling sites. When water chemistry changes synchronously, the relative rank of concentrations would be more resilient to temporal concentration variations because concentrations move up and down together (Erlandsson et al., 2008; Abbott et al., 2018a; Dupas et al., 2019).

\subsection{Statistical analysis}

Following equations 1 and 2, we quantified the $\mathrm{SP}_{\text {pairs }}$ and spatial $\mathrm{CV}$ for each sampling date for each parameter. We plotted $\mathrm{SP}_{\text {pairs }}$ against time to reveal its seasonal variation (section 3.1).

We also calculated the SP by the original method ( $S P_{\mathrm{FWC}}$, Abbott et al., 2018a), and made comparison with the $\mathrm{SP}_{\text {pairs }}$ from the new method (section 3.1).

The $\mathrm{SP}_{\mathrm{FWC}}$ is calculated as follows:

$$
\mathrm{SP}_{\mathrm{FWC}}=\operatorname{rcorr}\left(C_{t}, F W C\right)
$$

where the $\mathrm{SP}_{\mathrm{FWC}}$ at an individual sampling date $(\mathrm{t})$ is the Spearman's rank correlation coefficient (rcorr) between the concentrations of subcatchments at this sampling date $\left(\mathrm{C}_{\mathrm{t}}\right)$ and the flow-weighted mean concentrations (FWC) across the whole monitoring period.

The FWC is calculated as follows:

$$
\mathrm{FWC}=\frac{\sum_{t} C_{t} * Q_{t}}{\sum_{t} Q_{t}}
$$

This article is protected by copyright. All rights reserved. 
where $\mathrm{C}$ is the concentration and $\mathrm{Q}$ the discharge at the catchment outlet at the sampling date $(\mathrm{t})$.

We correlated the FWC for each parameter at each subcatchments with the subcatchment characteristics (land use, topography, soil properties, etc), to identify potential landscape drivers of the stream water chemistry (section 3.2).

We calculated the mean values of $\mathrm{SP}_{\text {pairs, }}$, spatial $\mathrm{CV}$, temporal $\mathrm{CV}$, and temporal synchrony for each parameter and computed pairwise correlations to identify linkages among those parameters. Finally, we used a multiple linear regression (MLR) model to explain the direct influence of spatial and temporal CV and temporal synchrony on $\mathrm{SP}_{\text {pairs }}$ (section 3.3).

All statistical analyses were performed with $\mathrm{R}$ version 3.6.1 (R Core Team, 2019). Correlations were considered significant at a confidence level of 0.05 . We used the Akaike information criterion (AIC) to select the variables to be included in the final model, the model having the lowest AIC being the best model.

\section{Results}

3.1 Variations of spatial persistence across seasons and flow conditions

The $\mathrm{SP}_{\text {pairs }}$ was high for most parameters with values ranging from 0.60 to 0.90 for most sampling dates (Figures 3, S2), despite large changes in concentration during the studied period (Figure S1). DOC, $\mathrm{F}^{-}, \mathrm{O}_{2}$, and $\mathrm{SUVA}_{254}$ had relatively low and variable $\mathrm{SP}_{\text {pairs, }}$ with average values between 0.40-0.52 as compared with 0.63-0.86 for the other parameters (Table 1). $\mathrm{SP}_{\text {pairs }}$ was lower in the summer dry season than in the winter wet season when $\mathrm{SP}_{\text {pairs }}$ was consistently high. This strong seasonality of $\mathrm{SP}_{\text {pairs }}$ was true for most parameters, except $\mathrm{F}^{-}$and $\mathrm{O}_{2}$ whose $\mathrm{SP}_{\text {pairs }}$ showed no seasonal signal during the study period. This seasonality of $\mathrm{SP}_{\text {pairs }}$ was more pronounced for DOC than other parameters (Figures 3, S2).

The seasonality in $\mathrm{SP}_{\mathrm{FWC}}$ was similar as for $\mathrm{SP}_{\text {pairs, }}$ but was higher in the wet season when most values ranged between 0.7-1.0 and decreased more rapidly in the dry season than $\mathrm{SP}_{\text {pairs }}$ (Figure S3). This difference was further confirmed by the higher mean values and standard deviations of $\mathrm{SP}_{\mathrm{FWC}}$ than $\mathrm{SP}_{\text {pairs }}$ for most parameters (Table 1, Figure $\mathbf{S 4}$ ). $\mathrm{SP}_{\text {pairs }}$ was strongly correlated with $\mathrm{SP}_{\mathrm{FWC}}$ for all parameters, with Pearson correlation coefficients ranging between 0.69-0.98 (Figure S5).

3.2 Spatiotemporal variations of water chemistry and the influence from catchment characteristics

Spatial CV was substantially higher for all forms of $\mathrm{C}, \mathrm{N}$, and $\mathrm{P}$, as well as for $\mathrm{F}^{-}$and $\mathrm{SO}_{4}{ }^{2-}$ during most sampling dates (Figure S6), with average values ranging between 0.34-0.85, than for the other parameters (ranging between 0.07-0.27, Table 1). For the different forms of $\mathrm{N}$ and $\mathrm{P}$ and for $\mathrm{SO}_{4}{ }^{2-}$, spatial $\mathrm{CV}$ exhibited a marked seasonality with higher values in the dry season than that in the wet season (Figure S6). Similar to spatial CV, temporal CV was substantially higher for different forms of $\mathrm{C}, \mathrm{N}$, and $\mathrm{P}$, as well as for $\mathrm{F}^{-}$and $\mathrm{SO}_{4}{ }^{2-}$ (Figure S6), with average values ranging between $0.27-0.77$, than for the other parameters (ranging between 0.09-0.16, Table 1). Temporal synchrony varied greatly among parameters, from 0.32 for $\mathrm{pH}$ to 0.88 for $\mathrm{O}_{2}$ (Table 1, Figure S6).

This article is protected by copyright. All rights reserved. 
For all water quality parameters except $\mathrm{DOC}, \mathrm{PP}, \mathrm{F}^{-}$, and $\mathrm{O}_{2}$, the temporal $\mathrm{CV}$ was lower than the spatial $\mathrm{CV}$, with ratios ranging between $0.47-0.98$, with the lowest values for SRP. For $\mathrm{DOC}, \mathrm{PP}, \mathrm{F}^{-}$and $\mathrm{O}_{2}$, the ratios ranged between 1.01-1.56 and their $\mathrm{SP}_{\text {pairs }}$ were generally lower than the other parameters.

Even though the studied subcatchments had highly diverse land properties and land use characteristics (Table S1), the relationships between these characteristics and the FWC values of monitored water parameters were typically weak with non-significant or low correlations $(|\mathrm{r}|<$ 0.6) (Figure S7). For different forms of C, N, and P, the strongest correlation appeared between the proportion of arable fields and $\mathrm{NO}_{3}{ }^{-}(\mathrm{r}=0.85)$. Land use composition, such as proportions of wetland, cultivated wetland, and pasture, had no relationship with most parameters. Mean soil depth and slope degree, together with proportions of Luvisols and forest were negatively correlated with FWC for most parameters. The other subcatchment landscape metrics, including proportions of arable land, winter crops, brown soil, and artificial drainage, all showed positive relationships with FWC for most parameters (Figure S7).

\subsection{Controls of spatial persistence in water chemistry}

Among parameters, $\mathrm{SP}_{\text {pairs }}$ was unrelated to spatial and temporal $\mathrm{CV}$ and temporal synchrony ( $\mathrm{p}>0.26$, Figure 4), demonstrating that the $\mathrm{SP}_{\text {pairs }}$ could not be determined simply by the overall magnitude of temporal and spatial variance or the synchrony of water chemistry variations among subcatchments. Similarly, temporal synchrony was not related to spatial or temporal CV ( $p>0.89$, Figure 4), suggesting the independence of water chemistry synchrony among subcatchments with magnitude of water chemistry temporal and spatial variance. Temporal CV was positively correlated with spatial CV ( $\mathrm{p}<0.001$, Figure 4). The temporal CV was generally lower than spatial $\mathrm{CV}$, as the ratio of temporal $\mathrm{CV} / \mathrm{spatial} \mathrm{CV}$ was smaller than 1 for 12 out of 16 parameters (Table 1, Figure 5).

The MLR model showed a good prediction of SP by a single predictor: the ratio of temporal CV/spatial CV, which explained $70 \%$ of the variance of $\mathrm{SP}_{\text {pairs }}$ (Figure 5a, AIC = 77.4). The performance of the MLR model was slightly improved by adding the temporal synchrony as the second predictor, with the variance of $\mathrm{SP}_{\text {pairs }}$ explained increasing to $74 \%$ (Figure 5b, AIC = -78.1).

\section{Discussion}

\subsection{Spatial persistence of water chemistry across seasons and flow conditions}

In an effort to improve characterization of pollution sources in mesoscale catchments (i.e. $100-1000 \mathrm{~km}^{2}$ ), we developed a new method to quantify the SP of water chemistry. The results demonstrated the value of occasional synoptic sampling in characterizing long-term water chemistry, with an average SP of 0.68 among parameters during the study period and values higher for crucial water quality parameters including $\mathrm{N}$ and $\mathrm{P}$ species (Table 1). The SP values calculated from the new method ( $\left.\mathrm{SP}_{\mathrm{pairs}}\right)$ are similar to those obtained using the original method (SPFC), but their standard deviations were smaller and the method does not depend on the estimation of the long-term concentration or flux metrics, which are often uncertain or unavailable. This approach thus increases the ease, precision, and applicability of this method to characterize the spatiotemporal behavior of water chemistry. The high SP found for parameters like TDP, SRP, and $\mathrm{NO}_{3}{ }^{-}$in the present study are consistent with previous research on the spatial

This article is protected by copyright. All rights reserved. 
patterns of water chemistry at seasonal to decadal timescales across ecoregions (Abbott et al., 2018a; Dupas et al., 2019; Shogren et al., 2019; Frei et al., 2020). The current study builds on this previous work by highlighting the mechanisms creating these persistent spatial patterns, and by revealing the influence of seasons and flow conditions on the SP of the 16 parameters studied.

We found that the $\mathrm{SP}_{\text {pairs }}$ is consistently high during the high-flow winter period (except for occasional storm events) but is low and more variable during the low-flow summer period for most parameters (Figures 3, S2). Three non-exclusive factors could explain the lower and more variable $\mathrm{SP}_{\text {pairs }}$ during the low-flow period. First, fluctuations of solute sources that determine the chemistry of the water discharged into the stream network. For example, the drawdown of the groundwater level is known to disconnect the stream from the shallow groundwater that drains the upland cultivated soils, switching the source of nutrients from cultivated soils to riparian wetlands and deep groundwater (Abbott et al., 2016; Gu et al., 2017; Li et al., 2021). This source fluctuation could create variability in stream water chemistry that could differ among parameters because shallow groundwater in this region is known for example to be enriched in $\mathrm{NO}_{3}{ }^{-}$, unlike riparian wetlands and deep groundwater which are mostly denitrified (Aubert et al., 2013; Abbott et al., 2018b; Kolbe et al., 2019). Second, the increasing importance of riparian and/or in-stream biogeochemical processes during the low-flow season could contribute to spatial instability in water chemistry patterns (Moatar et al., 2017). Decreased discharge increases residence time of solutes in different components of the stream network (e.g. riparian wetlands and hyporheic zones), while simultaneously decreases mass flux, thus increasing the exposure time to biogeochemical transformations and capacity for the in-stream and hyporheic community to modify concentrations and fluxes (Pinay et al., 2015; Wollheim et al., 2018; Kolbe et al., 2019; Casquin et al., 2020). A recent study on the concentration-discharge relationship in stream water supported this hypothesis, finding a dominant biogeochemical control on the concentrationdischarge slope when the discharge is below the median discharge (Moatar et al., 2017). The biogeochemical alteration of solutes could create variability unrelated to source fluctuations, which could explain why SP was low during this period of time for biologically reactive parameters, such as DOC (Figure 3; McGuire et al. 2014; Casas-Ruiz et al., 2017; Dong et al. 2017; Harjung et al., 2018). Third, the increasing importance of point source contribution during low flow. Point sources, such as leaking septic tanks, animal farming buildings, and wastewater treatment plants, are heterogeneously distributed in the landscape. Their influence on the annual loads may be small but may dominate the stream water chemistry at low flow, especially for elements enriched in those point source discharges like SRP, DOC, $\mathrm{Cl}^{-}$, etc (Withers et al., 2014b; Richards et al., 2016; Casquin et al., 2020).

During the high-flow winter period, the connectivity between solute sources in hillslopes and the stream network is high, leading to strong correlation between catchment solute sources and observed stream water chemistry (Raymond et al., 2016; Covino, 2017; Pinay et al., 2018). This creates high SP of water chemistry during this period. However, the hypothesis that the hydrological flux overwhelms biological factors during the high-flow period (Raymond et al., 2016; Moatar et al., 2017; Zarnetske et al., 2018) could differ among parameters, based on the timing of the drop in SP. The SP of more biologically reactive parameters (i.e. SRP, $\mathrm{NO}_{3}^{-}$, and DOC) decreased earlier than less reactive parameters (i.e. TDP, PP, and DIC) (Figure 3), which showed spatial reorganization as discharge dereased. These seasonally-lagged spatial rearrangements in chemistry suggest parameter-specific dynamics, potentially associated with stoichiometrically-regulated biological uptake and release, or complex multi-flowpath sources (Helton et al., 2015; Casquin et al., 2020; Frei et al., 2020; Lannergård et al., 2020).

This article is protected by copyright. All rights reserved. 


\subsection{Controls on the observed spatial persistence of water chemistry}

We found that the high $\mathrm{SP}_{\text {pairs }}$ for most parameters in the present study resulted from the combined contribution of the spatiotemporal variations in water chemistry and subcatchment synchrony, with $74 \%$ of its variance explained by the combined effects of the ratio between temporal and spatial CV, and temporal synchrony (Figure 5). However, the MLR indicated that $\mathrm{SP}_{\text {pars }}$ is primarily controlled by the ratios between temporal and spatial $\mathrm{CV}$ (explained variance: $70 \%$ ), in contrast with the weak influence of temporal synchrony alone (explained variance: $4 \%$ ). The larger variation in concentration among subcatchments at each date relative to the smaller temporal concentration variations at each site make the $\mathrm{SP}_{\text {pairs }}$ relatively independent of subcatchment synchrony, in line with previous findings (Dupas et al., 2019).

The pairwise correlations of $\mathrm{SP}_{\text {pairs }}$, spatial and temporal $\mathrm{CV}$, and temporal synchrony for the 16 investigated parameters showed positive and significant correlations only between spatial $\mathrm{CV}$ and temporal $\mathrm{CV}\left(\mathrm{r}^{2}=0.7\right.$; Figure 4), which has not been observed in previous studies (Abbott et al., 2018a; Dupas et al., 2019; Shogren et al., 2019). One possible explanation is that the agricultural land use in a catchment is not randomly distributed but inherently determined by catchment characteristics such as geology, soil type, and topography (Odgaard et al., 2013; Zabel et al., 2014; Thomas et al., 2016). For example, steep hillslopes are not well suited for agricultural cultivation and are more likely to remain undisturbed (e.g. forest), leading to a negative relationship between mean slope and FWC for most parameters (Figures S7, S8). Conversely, brown soil makes good agricultural land due to high fertility and active soil fauna, resulting in the positive relationships between brown soil and FWC for most parameters (Figure S7). This human-mediated linkage between catchment attributes and water quality parameters appears widespread in the Anthropocene. Subcatchments with different agricultural land use will have different initial resilience to solute loading, though the nonrandom distribution of human disturbance can offset or nullify this initial template (Thomas et al., 2016; Frei et al., 2020), thus creating a land use-driven linkage between the spatial and temporal variations in water chemistry. Another possible explanation is that sources of anthropogenic solutes $(\mathrm{N}$ and $\mathrm{P})$ are concentrated near the soil surface where they are applied (Sebilo et al., 2013; Van Meter et al., 2016; Abbott et al., 2018b; Botter et al., 2020), generating large vertical gradients of $\mathrm{N}$ and $\mathrm{P}$ content in the soil profile and vadose zone. Additionally, sources of these solutes are also spatially variable because the degree of agricultural intensification varies across the gradient from $100 \%$ forest to $100 \%$ agriculture. With the changes in water flowpath on seasonal scales (wet vs. dry seasons) or on event scales (stormflow vs. baseflow), the convolution of high vertical variation with the large lateral variability could result in the high spatial and temporal $\mathrm{CV}$ of these solutes in stream water (e.g. all forms of $\mathrm{N}$ and P, Table 1). On the contrary, geogenic solute sources are more evenly distributed vertically and spatially, resulting in both low spatial and temporal CV for these solutes (Godsey et al., 2009).

\subsection{Implications for improved characterization of water chemistry}

By using pairwise rank correlations among sampling dates, the new method to quantify SP developed in the present study avoids using metrics calculated from medium-frequency monitoring datasets, which usually introduce large uncertainties (Cassidy and Jordan, 2011; Lloyd et al., 2015; Skeffington et al., 2015). An important finding of the present study is that a synoptic sampling during the high-flow season increases the representativeness of monitoring on the long-term spatial structure of water chemistry. If this pattern applies in other ecosystem types

This article is protected by copyright. All rights reserved. 
and land-use regimes, this will be of great practical importance for regions of the world with low density of monitoring networks and low frequency of monitoring, especially in developing countries where the water quality is degrading rapidly (Seitzinger et al., 2010; Crocker and Bartram, 2014). An implication of our findings is that specific monitoring campaigns should be done during low-flow periods, when spatial persistence is lower and nutrient sources are probably not the same as high-flow periods. In many regions, the symptoms of eutrophication such as cyanobacteria blooms and dead zones occur most frequently and intensely during periods of low flow. Likewise, human use of surface and groundwater is often higher during these periods, requiring additional monitoring and mitigation to avoid societal damages (Abbott et al., 2019).

Thus far, relatively high spatial persistence of nutrients and major ions has been observed in temperate oceanic ecoregions (Abbot et al., 2018a; this study; Frei et al., 2020), various other temperate ecoregions (Dupas et al., 2019; Weller and Jordan, 2020), and in the Boreal and Arctic (Temnerud et al., 2005; Shogren et al., 2019). Additional research is needed in other ecoregions, including arid, semi-arid, and wet/dry and wet tropics where most developing countries are located. Additionally, the current study confirmed the applicability of the SP concept to a broad suite of water quality parameters (including conductivity, $\mathrm{pH}, \mathrm{SUVA}_{254}$, etc.), suggesting the potential utility of this metric in characterizing spatial patterns of other crucial parameters of concern, such as suspended sediments, and emerging contaminants (e.g. pharmaceuticals, microplastics, and other novel micropollutants). We assessed the sensitivity of $\mathrm{SP}_{\text {pairs }}$ to the number of sampling campaigns (Figure 6), by calculating the $\mathrm{SP}_{\text {pairs }}$ with decreasing number of randomly selected sampling campaigns (out of the 31 samplings). According to our sensitivity analysis, verifying the $\mathrm{SP}_{\text {pairs }}$ for new water quality parameters or in a different ecoregion would need 7 to 14 sampling dates (Figure 6). Once a high $\mathrm{SP}_{\text {pairs }}$ is verified for a parameter of concern in a given context, it allows fast identification of source and sink subcatchments, as only one synoptic sampling can be representative of the long-term spatial structure of water chemistry (Abbot et al., 2018a; Dupas et al., 2019; this study).

Another important finding of the present study is that the spatial variability of a given parameter is correlated with its temporal variability (Figure 4). Trading "space for time" is a common method in hydrology and is a potentially crucial tool to advance water quality understanding and modelling (Singh et al., 2011). For example, a recent study has tried to draw guidelines on recommending sampling frequency as a function of temporal variability of the parameters of concern (e.g. TP, $\mathrm{NO}_{3}^{-}$, and DOC) (Moatar et al., 2020). Thus, an interesting application of the present work would be to draw guidelines on sampling spatial density depending on the spatial variability and SP of the parameters of concern. Our findings have different implications for the monitoring of different water chemistry parameters. For parameters with a relatively high $\mathrm{SP}_{\text {pairs }}$ and a spatial $\mathrm{CV}$ higher than temporal $\mathrm{CV}$ (e.g. all forms of $\mathrm{N}$ and $\mathrm{P}$, Table 1), the influence of spatial heterogeneity on the overall variability of those parameters will be greater than the influence of temporal variation magnitude. A sampling strategy with higher spatial intensity but lower frequency will be sufficient to account for the variations of these parameters and provide adequate information about catchment-scale source identification. On the contrary, for parameters such as $\mathrm{DOC}, \mathrm{F}^{-}$, and $\mathrm{O}_{2}$ that had a poor $\mathrm{SP}_{\text {pairs }}$ and a spatial $\mathrm{CV}$ lower than temporal CV (Table 1), a sampling strategy with higher frequency at a certain spatial intensity would be more appropriate to account for the variations of these parameters. Overall, the present study could contribute to increasing the efficiency of management efforts, by

This article is protected by copyright. All rights reserved. 
optimizing the sampling strategy of the water quality parameters that are of greater ecological concern.

\section{Conclusions}

We developed a new method to quantify the spatial persistence of water chemistry to reduce the dependence on the uncertain estimation of long-term metrics. The test of this method in a mesoscale catchment resulted in high SP values for most parameters, confirming the value of an occasional synoptic sampling in representing the spatial structure of water chemistry during a certain period for a broad suite of parameters. Spatial persistence of water chemistry varied seasonally for most of the parameters studied, being consistently high during the high-flow winter period and was low and variable during the low-flow summer period. Among variables, we found that the spatial persistence was ultimately controlled by the ratio between temporal and spatial CV with a weak influence from temporal synchrony. Overall, the seasonal pattern in spatial persistence of water chemistry revealed that a synoptic sampling during the high-flow season will better represent the long-term spatial structure of water chemistry, potentially contributing to the development of monitoring and management measures with higher efficiency, especially for developing countries.

\section{Acknowledgments}

The study was funded by the Interreg project Channel Payments for Ecosystem Services through the European Regional Development Fund (ERDF), and by the National Natural Science Foundation of China (41877397). BWA was supported by the U.S. National Science Foundation award \#2011439. We would like to thank Sophie Moisan and Ewan Couic for their assistant in field sampling. The authors also thank the editors and reviewers for their constructive suggestions.

\section{Data Availability Statement}

The data used to support these findings of this publication are available at: http://www.hydroshare.org/resource/7c7d7f6dd1f14450883ae1c243c3c28f

\section{References}

Abbott, B.W., et al. (2016). Using multi-tracer inference to move beyond single-catchment ecohydrology. Earth-Science Reviews, 160, 19-42. https://doi.org/10.1016/j.earscirev.2016.06.014

Abbott, B.W., et al. (2018a). Unexpected spatial stability of water chemistry in headwater stream networks. Ecology Letters, 21(2), 296-308. https://doi.org/10.1111/ele.12897

Abbott, B.W., Moatar, F., Gauthier, O., Fovet, O., Antoine, V., \& Ragueneau, O. (2018b). Trends and seasonality of river nutrients in agricultural catchments: 18 years of weekly citizen science in France. Science of the Total Environment, 624, 845-858. https://doi.org/10.1016/j.scitotenv.2017.12.176

Abbott, B.W., et al. (2019). A Water Cycle for the Anthropocene. Hydrological Processes, 33(23), 3046-3052. https://doi.org/10.1002/hyp.13544

Alilou, H., Moghaddam Nia, A, Saravi, M.M., Salajegheh, A., Han, D., \& Bakhtiari Enayat, B. (2019). A novel approach for selecting sampling points locations to river water quality monitoring in datascarce regions. Journal of Hydrology, 573, 109-122. https://doi.org/10.1016/j.jhydrol.2019.03.068

This article is protected by copyright. All rights reserved. 
Aubert, A.H., et al. (2013). Solute transport dynamics in small, shallow groundwater-dominated agricultural catchments: insights from a high-frequency, multisolute 10 yr-long monitoring study. Hydrology and Earth System Sciences, 17, 1379-1391. https://doi.org/10.5194/hess-17-1379-2013

Bieroza, M.Z., Heathwaite, A.L., Bechmann, M., Kyllmar, K., \& Jordan, P. (2018). The concentrationdischarge slope as a tool for water quality management. Science of the Total Environment, 630, 738-749. https://doi.org/10.1016/j.scitotenv.2018.02.256

Bishop, K., et al. (2008). Aqua incognita: the unknown headwaters. Hydrological Processes, 22(8), 12391242. https://doi.org/10.1002/hyp.7049

Bogena, H. R., White, T., Bour, O., Li, X., \& Jensen, K. H. (2018). Toward better understanding of terrestrial processes through long-term hydrological observatories. Vadose Zone Journal, 17(1). https://doi.org/10.2136/vzj2018.10.0194

Bol, R., et al. (2018). Challenges of reducing phosphorus based water eutrophication in the agricultural landscapes of Northwest Europe. Frontiers in Marine Science, 5. https://doi.org/10.3389/fmars.2018.00276

Botter, M., Li, L., Hartmann, J., Burlando, P., \& Fatichi, S. (2020). Depth of solute generation is a dominant control on concentration- discharge relations. Water Resources Research, 56(8), e2019WR026695, https://doi.org/10.1029/2019WR026695

Bowes, M.J., et al. (2015). Characterising phosphorus and nitrate inputs to a rural river using high-frequency concentration-flow relationships. Science of the Total Environment, 511, 608-620. https://doi.org/10.1016/j.scitotenv.2014.12.086

Casas-Ruiz, J.P., et al. (2017). A tale of pipes and reactors: Controls on the in-stream dynamics of dissolved organic carbon in rivers. Limnology and Oceanography, 62, S85-S94. https://doi.org/10.1002/lno.10471

Cassidy, R., \& Jordan, P. (2011). Limitations of instantaneous water quality sampling in surface-water catchments: Comparison with near-continuous phosphorus time-series data. Journal of Hydrology, 405, 182193. https://doi.org/10.1016/j.jhydrol.2011.05.020

Casquin, A., Gu, S., Dupas, R., Petitjean, P., Gruau, G., \& Durand, P. (2020). River network alteration of C-N$\mathrm{P}$ dynamics in a mesoscale agricultural catchment. Science of the Total Environment, 749, 141551. https://doi.org/10.1016/j.scitotenv.2020.141551

Conley, D.J., et al. (2009). Controlling Eutrophication: Nitrogen and Phosphorus. Science, 323(5917), 10141015. https://doi.org/10.1126/science. 1167755

Covino, T. (2017). Hydrologic connectivity as a framework for understanding biogeochemical flux through watersheds and along fluvial networks. Geomorphology, 277, 133-144. https://doi.org/10.1016/j.geomorph.2016.09.030

Crocker, J., \& Bartram, J. (2014). Comparison and Cost Analysis of Drinking Water Quality Monitoring Requirements versus Practice in Seven Developing Countries. International Journal of Environmental Research and Public Health, 11(7), 7333-7346. https://doi.org/10.3390/ijerph110707333

Dong, X., Ruhí, A., \& Grimm, N.B. (2017). Evidence for self-organization in determining spatial patterns of stream nutrients, despite primacy of the geomorphic template. Proceedings of the National Academy of Sciences of the United States of America, 114(24), E4744-E4752. https://doi.org/10.1073/pnas.1617571114

Downing, J. (2012). Global abundance and size distribution of streams and rivers. Inland Waters, 2(4), 229236. https://doi.org/10.5268/IW-2.4.502

Dupas, R., Minaudo, C., Gruau, G., Ruiz, L., \& Gascuel-Odoux, C. (2018). Multidecadal trajectory of riverine nitrogen and phosphorus dynamics in rural catchments. Water Resources Research, 54, 5327-5340. https://doi.org/10.1029/2018WR022905

This article is protected by copyright. All rights reserved. 
Dupas, R., Minaudo, C., \& Abbott, B. W. (2019). Stability of spatial patterns in water chemistry across temperate ecoregions. Environmental Research Letters, 14, 074015. https://doi.org/10.1088/17489326/ab24f4

Erlandsson, M., et al. (2008). Thirty-five years of synchrony in the organic matter concentrations of Swedish rivers explained by variation in flow and sulphate. Global Change Biology, 14(5), 1191-1198. https://doi.org/10.1111/j.1365-2486.2008.01551.x

Fovet, O., et al. (2018). Seasonal variability of stream water quality response to storm events captured using high-frequency and multi-parameter data. Journal Hydrology, 559, 282-293.

https://doi.org/10.1016/j.jhydrol.2018.02.040

Frei, R.J., et al. (2020). Predicting Nutrient Incontinence in the Anthropocene at Watershed Scales. Frontiers in Environmental Science, 7, 200. https://doi.org/10.3389/fenvs.2019.00200

Godsey, S.E., Kirchner, J.W., \& Clow, D.W. (2009). Concentration-Discharge Relationships Reflect Chemostatic Characteristics of US Catchments. Hydrological Processes, 23(13), 1844-1864. https://doi.org/10.1002/hyp.7315

Gu S., et al. (2017). Release of dissolved phosphorus from riparian wetlands: evidence for the complex interplay of soil characteristics, groundwater dynamics, and biogeochemical processes. Science of the Total Environment, 598, 421-431. https://doi.org/10.1016/j.scitotenv.2017.04.028

Guo, D., et al. (2018). Key factors affecting temporal variability in stream water quality. Water Resources Research, 55(1), 112-129. https://doi.org/10.1029/2018WR023370

Hammond, M.P., \& Kolasa, J. (2014). Spatial variation as a tool for inferring temporal variation and diagnosing types of mechanisms in ecosystems. PLoS ONE, 9, e89245. https://doi.org/10.1371/journal.pone.0089245

Harjung, A., Sabater, F., \& Butturini, A. (2018). Hydrological Connectivity Drives Dissolved Organic Matter Processing in an Intermittent Stream. Limnologica, 68, 71-81. https://doi.org/10.1016/j.limno.2017.02.007

Helton, A.M., Ardon, M., \& Bernhardt, E.S. (2015). Thermodynamic constraints on the utility of ecological stoichiometry for explaining global biogeochemical patterns. Ecology Letters, 18(10), 1049-1056 https://doi.org/10.1111/ele.12487

Helton, A.M., Hall, R.O., \& Bertuzzo, E. (2018). How Network Structure Can Affect Nitrogen Removal by Streams. Freshwater Biology, 63(1), 128-140. https://doi.org/10.1111/fwb.12990

Hering, D., et al. (2010). The European Water Framework Directive at the age of 10: A critical review of the achievements with recommendations for the future. Science of the Total Environment, 408(19), 4007-4019. https://doi.org/10.1016/j.scitotenv.2010.05.031

Ibarrola-Rivas, M.J., Granados-Ramírez, R., \& Nonhebel, S. (2017). Is the available cropland and water enough for food demand? A global perspective of the Land-Water-Food nexus. Advances in Water Resources, 110, 476-483. https://doi.org/10.1016/j.advwatres.2017.09.018

Jenny, J.-P., et al. (2016). Urban point sources of nutrients were the leading cause for the historical spread of hypoxia across European lakes. Proceedings of the National Academy of Sciences of the United States of America, 113(45), 12655-12660. https://doi.org/10.1073/pnas.1605480113

Johnes, P.J. (2007). Uncertainties in annual riverine phosphorus load estimation: Impact of load estimation methodology, sampling frequency, baseflow index and catchment population density. Journal of Hydrology, 332, 241-258. https://doi.org/10.1016/j.jhydrol.2006.07.006

Jordan, T.E., Correll, D.L., \& Weller, D.E. (1997). Relating nutrient discharges from watersheds to land use and streamflow variability. Water Resources Research, 33, 2579-2590. https://doi.org/10.1029/97WR02005

This article is protected by copyright. All rights reserved. 
Kirchner, J.W., \& Neal, C. (2013). Universal fractal scaling in stream chemistry and its implications for solute transport and water quality trend detection. Proceedings of the National Academy of Sciences of the United States of America, 110(30), 12213-12218. https://doi.org/10.1073/pnas.1304328110

Kleinman, P.J.A., et al. (2019). Phosphorus and the Chesapeake Bay: Lingering issues and emerging concerns for agriculture. Journal of Environmental Quality, 48, 1191-1203. https://doi.org/10.2134/jeq2019.03.0112

Kolbe, T., et al. (2019). Stratification of reactivity determines nitrate removal in groundwater. Proceedings of the National Academy of Sciences of the United States of America, 116, 2494-2499. https://doi.org/10.1073/ pnas. 1816892116

Landrigan, P.J., et al. (2017). The Lancet Commission on pollution and health. Lancet, 391, 462-512. https://doi.org/10.1016/S0140-6736(17)32345-0

Lannergård, E.E., Agstam-Norlin, O., Huser, B.J., Sandström, S., Rakovic, J., \& Futter, M.N. (2020). New insights into legacy phosphorus from fractionation of streambed sediment. Journal of Geophysical Research: Biogeosciences, 125(9), e2020JG005763. https://doi.org/10.1029/2020JG005763

Le Moal, M. et al., (2018). Eutrophication: A new wine in an old bottle? Science of the Total Environment, 651, 1-11. https://doi.org/10.1016/j.scitotenv.2018.09.139

Lefebvre, S., Clément, J.-C., Pinay, G., Thenail, C., Durand, P., \& Marmonier, P. (2007). ${ }^{15} \mathrm{~N}$-nitrate signature in low-order streams: effects of land cover and agricultural practices. Ecological Applications, 17, 2333 2346. https://doi.org/10.1890/06-1496.1

Li, L., et al. (2021). Toward Catchment Hydro-Biogeochemical Theories. Wiley Interdisciplinary ReviewsWater, 8(1), e1495. https://doi.org/10.1002/wat2.1495

Lintern, A., et al. (2018). What are the key catchment characteristics affecting spatial differences in riverine water quality? Water Resources Research, 54(10), 7252-7272. https://doi.org/10.1029/2017WR022172

Lloyd, C.E.M., Freer, J.E., Johnes, P.J., Coxon, G., \& Collins, A.L. (2015). Discharge and nutrient uncertainty: implications for nutrient flux estimation in small streams. Hydrological Processes, 30, 135-152. https://doi.org/10.1002/hyp.10574

McGuire, K.J., Torgersen, C.E., Likens, G.E., Buso, D.C., Lowe, W.H., \& Bailey, S.W. (2014). Network analysis reveals multiscale controls on stream water chemistry. Proceedings of the National Academy of Sciences of the United States of America, 111(19), 7030-7035. https://doi.org/10.1073/pnas.1404820111

Matthews, M.W. (2014). Eutrophication and cyanobacterial blooms in South African inland waters: 10 years of MERIS observations. Remote Sensing of Environment, 155, 161-177. https://doi.org/10.1016/j.rse.2014.08.010

Mentzafou, A., Panagopoulos, Y., \& Dimitriou, E. (2019). Designing the National Network for Automatic Monitoring of Water Quality Parameters in Greece. Water, 11(6), 1310. https://doi.org/10.3390/w11061310

Moatar, F., Abbott, B.W., Minaudo, C., Curie, F., \& Pinay, G. (2017). Elemental properties, hydrology, and biology interact to shape concentration-discharge curves for carbon, nutrients, sediment, and major ions. Water Resources Research, 53, 1270-1287. https://doi.org/10.1002/2016WR019635

Moatar, F., et al. (2020). Stream solutes and particulates export regimes: A new framework to optimize their monitoring. Frontiers in Ecology and Evolution, 7, 516. https://doi.org/10.3389/fevo.2019.00516

Murphy, J., \& Riley, J.P. (1962). A modified single solution method for the determination of phosphate in natural waters. Analytica Chimica Acta, 27, 31-36. https://doi.org/10.1016/S0003-2670(00)88444-5

Odgaard, M.V., Bøcher, P.K., Dalgaard, T., Moeslund, J.E. \& Svenning, J.-C. (2013). Human-driven topographic effects on the distribution of forest in a flat, lowland agricultural region. Journal of Geographical Sciences, 24, 76-92. https://doi.org/10.1007/s11442-014-1074-6

ODEM. (2012). Apports de phosphore et proliférations de cyanobactéries dans le Lac au Duc (Morbihan), pp. 191

This article is protected by copyright. All rights reserved. 
Pinay, G., et al. (2015). Upscaling nitrogen removal capacity from local hotspots to low stream orders' drainage basins. Ecosystems, 18, 1101-1120. https://doi.org/10.1007/s10021-015-9878-5

Pinay, G., et al. (2018). Riparian corridors: a new conceptual framework for assessing nitrogen buffering across biomes. Frontiers in Environmental Science, 6. https://doi.org/10.3389/fenvs.2018.00047

Raymond, P.A., Saiers, J.E. \& Sobczak, W.V. (2016). Hydrological and biogeochemical controls on watershed dissolved organic matter transport: pulse-shunt concept. Ecology, 97(1), 5-16. https://doi.org/10.1890/141684.1

Richards, S., Withers, P., Paterson, E., C.W., M., \& Stutter, M. (2016) Temporal variability in domestic point source discharges and their associated impact on receiving waters. Science of the Total Environment, 571, 1275-1283. https://doi.org/10.1016/j.scitotenv.2016.07.166

Rode, M., et al. (2016). Sensors in the Stream: The High-Frequency Wave of the Present. Environmental Science \& Technology, 50(19), 10297-10307. https://doi.org/10.1021/acs.est.6b02155

Schilling, K.E., Jones, C.S. \& Seeman, A. (2013). How paired is paired? Comparing nitrate concentrations in three iowa drainage districts. Journal of Environmental Quality, 42(5), 1412. https://doi.org/10.2134/jeq2013.03.0085

Sebilo, M., Mayer, B., Nicolardot, B., Pinay, G., \& Mariotti, A. (2013). Long-Term Fate of Nitrate Fertilizer in Agricultural Soils. Proceedings of the National Academy of Sciences of the United States of America, 110(45), 18185-18189. https://doi.org/10.1073/pnas.1305372110

Seitzinger, S.P., et al. (2010). Global river nutrient export: a scenario analysis of past and future trends. Global Biogeochemical Cycles, 24(4), GB0A08. https://doi.org/10.1029/2009GB003587

Shogren, A.J., et al. (2019). Revealing Biogeochemical Signatures of Arctic Landscapes with River Chemistry. Scientific Reports, 9, 1-11. https://doi.org/10.1038/s41598-019-49296-6

Shogren, A.J., Zarnetske, J.P., Abbott, B.W., Iannucci, F., \& Bowden, W.B. (2020). We Cannot Shrug off the Shoulder Seasons: Addressing Knowledge and Data Gaps in an Arctic Headwater. Environmental Research Letters, 15, 104027. https://doi.org/10.1088/1748-9326/ab9d3c

Singh, R., Wagener, T., van Werkhoven, K., Mann, M.E., \& Crane, R. (2011). A trading-space-for-time approach to probabilistic continuous streamflow predictions in a changing climate-Accounting for changing watershed behavior. Hydrology and Earth System Sciences, 15, 3591-3603. https://doi.org/10.5194/hess-15-3591-2011

Sinha, E., Michalak, A.M., Calvin, K.V., \& Lawrence, P.J. (2019). Societal Decisions about Climate Mitigation Will Have Dramatic Impacts on Eutrophication in the 21 St Century. Nature Communications, 10 (939). https://doi.org/10.1038/s41467-019-08884-w

Skeffington, R.A., Halliday, S.J., Wade, A.J., Bowes, M.J., \& Loewenthal, M. (2015). Using high-frequency water quality data to assess sampling strategies for the EU Water Framework Directive. Hydrology and Earth System Sciences, 19, 2491-2504. https://doi.org/10.5194/hess-19-2491-2015

Strayer, D.L., et al. (2003). Effects of Land Cover on Stream Ecosystems: Roles of Empirical Models and Scaling Issues. Ecosystems, 6, 407-423. https://doi.org/10.1007/PL00021506

Sutton, M.A., Oenema, O., Erisman, J.W., Leip, A., van Grinsven, H., \& Winiwarter, W. (2011). Too much of a good thing. Nature, 472, 159-161. https://doi.org/10.1038/472159a

Temnerud, J., \& Bishop, K. (2005). Spatial Variation of Streamwater Chemistry in Two Swedish Boreal Catchments: Implications for Environmental Assessment. Environmental Science \& Technology, 39(6), 1463-1469. https://doi.org/10.1021/es040045q

Thomas, Z., Abbott, B.W., Troccaz, O., Baudry, J., \& Pinay, G. (2016). Proximate and ultimate controls on carbon and nutrient dynamics of small agricultural catchments. Biogeosciences, 13, 1863-1875. https://doi.org/10.5194/bg-13-1863-2016

This article is protected by copyright. All rights reserved. 
UNICEF. (2019). Progress on household drinking water, sanitation and hygiene 2000-2017. Special focus on inequalities. New York: United Nations Children's Fund (UNICEF) and World Health Organization.

Van Meter, K.J., Basu, N.B., \& Van Cappellen, P. (2017). Two Centuries of Nitrogen Dynamics: Legacy Sources and Sinks in the Mississippi and Susquehanna River Basins. Global Biogeochemical Cycles, 31, 223. https://doi.org/10.1002/2016GB005498

Van Meter, K.J., Basu, N.B., Veenstra, J.J., \& Burras, C.L. (2016). The Nitrogen Legacy: Emerging Evidence of Nitrogen Accumulation in Anthropogenic Landscapes. Environmental Research Letters, 11(3), 035014. https://doi.org/10.1088/1748-9326/11/3/035014

Vörösmarty, C.J., et al. (2010). Global threats to human water security and river biodiversity. Nature, 467, 555-561. https://doi.org/10.1038/nature09440

Ward, M.H., et al. (2018). Drinking water nitrate and human health: An updated review. International Journal of Environmental Research and Public Health, 15(7), 1557. https://doi.org/10.3390/ijerph15071557

Weller, D.E., \& Jordan, T.E. (2020). Inexpensive spot sampling provides unexpectedly effective indicators of watershed nitrogen status. Ecosphere, 11(8), e03224. https://doi.org/10.1002/ecs2.3224

Withers, P.J.A., Neal, C., Jarvie, H.P., \& Doody, D.G. (2014a). Agriculture and eutrophication: where do we go from here? Sustainability, 6, 5853-5875. https://doi.org/10.3390/su6095853

Withers, P.J.A., Jordan, P., May, L., Jarvie, H.P., \& Deal, N.E. (2014b). Do septic tank systems pose a hidden threat to water quality? Frontiers in Ecology and the Environment, 12(2), 123-130. https://doi.org/10.1890/130131

Wollheim, W.M., et al. (2018). River network saturation concept: factors influencing the balance of biogeochemical supply and demand of river networks. Biogeochemistry, 141, 503-521.

https://doi.org/10.1007/s10533-018-0488-0

Wurtsbaugh, W.A., Paerl, H.W., \& Dodds, W.K. (2019). Nutrients, Eutrophication and Harmful Algal Blooms along the Freshwater to Marine Continuum. Wiley Interdisciplinary Reviews-Water, 6(5), e1373. https://doi.org/10.1002/wat2.1373

Yang, X., Jomaa, S., Zink, M., Fleckenstein, J. H., Borchardt, D., \& Rode, M. (2018). A new fully distributed model of nitrate transport and removal at catchment scale. Water Resources Research, 54(8), 5856-5877. https://doi.org/10.1029/2017WR022380

Zabel, F., Putzenlechner, B., \& Mauser, W. (2014). Global agricultural land resources - A high resolution suitability evaluation and its perspectives until 2100 under climate change conditions. PLoS ONE, 9(12), e107522. https://doi.org/10.1371/journal.pone.0107522

Zarnetske, J.P., Bouda, M., Abbott, B.W., Saiers, J., \& Raymond, P.A. (2018). Generality of Hydrologic Transport Limitation of Watershed Organic Carbon Flux Across Ecoregions of the United States. Geophysical Research Letters, 45, 11702-11711. https://doi.org/10.1029/2018GL080005

This article is protected by copyright. All rights reserved. 


\section{Figure Captions:}

Figure 1. Hydrographic network and sampling points in the Yvel catchment. Hatched areas show the monitored headwater subcatchments. Discharge was measured at the white dot, near the Yvel catchment outlet.

Figure 2. Conceptual diagram of how water chemistry could vary through space and time. Each plane represents an individual sampling date. Dots on the plane represent the sampling sites, which have a variety of catchment areas and solute concentrations. Colored dots linked by lines represent the concentration time-series for a specific sampling site. High spatial persistence of water chemistry could result from a much higher spatial CV than the temporal CV, or from high temporal synchrony among subcatchments (i.e. concentrations move up and down synchronously). The diagram was inspired by Hammond and Kolasa (2014).

Figure 3. Time series of the spatial persistence ( $\left.\mathrm{SP}_{\text {pairs }}\right)$ for (a) total dissolved $\mathrm{P}$ (TDP), soluble reactive $\mathrm{P}(\mathrm{SRP})$, dissolved organic $\mathrm{C}(\mathrm{DOC})$, nitrate $\left(\mathrm{NO}_{3}{ }^{-}\right)$, and $(\mathrm{b})$ total $\mathrm{P}(\mathrm{TP})$, particulate $\mathrm{P}$ (PP), dissolved inorganic $\mathrm{C}$ (DIC) and nitrite $\left(\mathrm{NO}_{2}^{-}\right)$. (c) Daily discharge at the Yvel gauging station and dates of sampling (red dots). See Fig. S1 for the same information for the other 8 analyzed parameters.

Figure 4. Pairwise comparison among spatial persistence ( $\left.\mathrm{SP}_{\text {pairs }}\right)$, spatial and temporal coefficient of variation (CV), and temporal synchrony (average per parameter). Error bars represent \pm standard deviation.

Figure 5. Spatial persistence (average per parameter) as a function of (a) temporal CV/spatial $\mathrm{CV}$ (TCV/SCV) and (b) the multiple linear regression predictions based on TCV/SCV and temporal synchrony.

Figure 6. Sensitivity of mean spatial persistence to the number of sampling dates for three parameters with low (DOC), high (TDP) and very high $\left(\mathrm{NO}_{3}^{-}\right)$spatial persistence. (a) Values of mean $\mathrm{SP}_{\text {pairs }}$ for 500 random draws given the number of sampling dates (dots). The green dashed lines represent the mean $\mathrm{SP}_{\text {pair }}$ computed on all the dates (same as Table 1) and the green ribbons represent an interval of $+/-0.1$ around this value. (b) Proportions of values of $\mathrm{SP}_{\text {pairs }}$ that fall within this interval according to the number of sampled dates. Blue dashed lines indicate the minimum number of dates to sample to have $90 \%$ of the $\mathrm{SP}_{\text {pairs }}$ within this $+/-0.1$ interval.

This article is protected by copyright. All rights reserved. 


\section{Table:}

Table 1. Mean (standard deviation) of spatial persistence ( $\mathrm{SP}_{\text {pairs }}$ ) and spatial CV (SCV) (mean of all dates), and of temporal CV (TCV) and temporal synchrony (Syn) (mean of all sites) for each parameter. $\mathrm{SP}_{\mathrm{FWC}}$ is the $\mathrm{SP}$ calculated from flow-weighted mean concentration.

\begin{tabular}{ccccccc}
\hline & $\mathrm{SP}_{\text {pairs }}$ & $\mathrm{SCV}$ & $\mathrm{TCV}$ & $\mathrm{Syn}$ & $\mathrm{TCV} / \mathrm{SCV}$ & $\mathrm{SP}_{\text {FWC }}$ \\
\hline $\mathrm{TDP}$ & $0.71(0.11)$ & $0.79(0.35)$ & $0.47(0.14)$ & $0.59(0.10)$ & 0.60 & $0.78(0.18)$ \\
$\mathrm{SRP}$ & $0.74(0.11)$ & $0.85(0.41)$ & $0.40(0.20)$ & $0.64(0.13)$ & 0.47 & $0.82(0.15)$ \\
$\mathrm{DOC}$ & $0.46(0.17)$ & $0.34(0.08)$ & $0.39(0.12)$ & $0.59(0.11)$ & 1.13 & $0.58(0.33)$ \\
$\mathrm{NO}_{3}{ }^{-}$ & $0.80(0.10)$ & $0.64(0.11)$ & $0.41(0.19)$ & $0.60(0.17)$ & 0.64 & $0.83(0.17)$ \\
$\mathrm{TP}$ & $0.76(0.11)$ & $0.67(0.24)$ & $0.51(0.14)$ & $0.59(0.12)$ & 0.76 & $0.81(0.14)$ \\
$\mathrm{PP}$ & $0.63(0.14)$ & $0.76(0.20)$ & $0.77(0.25)$ & $0.38(0.09)$ & 1.01 & $0.73(0.19)$ \\
$\mathrm{DIC}$ & $0.79(0.10)$ & $0.47(0.06)$ & $0.37(0.21)$ & $0.64(0.16)$ & 0.78 & $0.85(0.15)$ \\
$\mathrm{NO}_{2}^{-}$ & $0.78(0.12)$ & $0.55(0.27)$ & $0.53(0.28)$ & $0.70(0.17)$ & 0.98 & $0.83(0.17)$ \\
\hline $\mathrm{F}^{-}$ & $0.43(0.18)$ & $0.40(0.21)$ & $0.52(0.23)$ & $0.57(0.06)$ & 1.30 & $0.60(0.25)$ \\
$\mathrm{Br}^{-}$ & $0.71(0.16)$ & $0.16(0.03)$ & $0.14(0.05)$ & $0.57(0.15)$ & 0.85 & $0.78(0.22)$ \\
$\mathrm{Cl}^{-}$ & $0.80(0.09)$ & $0.15(0.04)$ & $0.09(0.03)$ & $0.53(0.15)$ & 0.60 & $0.85(0.12)$ \\
$\mathrm{SO}_{4}{ }^{2-}$ & $0.76(0.16)$ & $0.38(0.08)$ & $0.27(0.10)$ & $0.66(0.17)$ & 0.70 & $0.82(0.17)$ \\
$\mathrm{pH}^{-}$ & $0.68(0.23)$ & $0.08(0.02)$ & $0.05(0.03)$ & $0.33(0.24)$ & 0.57 & $0.69(0.20)$ \\
$\mathrm{O}_{2}$ & $0.40(0.11)$ & $0.07(0.04)$ & $0.11(0.03)$ & $0.90(0.07)$ & 1.56 & $0.58(0.21)$ \\
$\mathrm{Cond}^{-}$ & $0.86(0.16)$ & $0.27(0.04)$ & $0.13(0.05)$ & $0.46(0.13)$ & 0.50 & $0.87(0.17)$ \\
$\mathrm{SUVA}_{254}$ & $0.52(0.23)$ & $0.19(0.05)$ & $0.16(0.06)$ & $0.46(0.27)$ & 0.87 & $0.66(0.29)$ \\
\hline $\mathrm{mean}^{(\mathrm{sd})}$ & $0.68(0.15)$ & $0.42(0.26)$ & $0.33(0.21)$ & $0.58(0.13)$ & $0.83(0.30)$ & $0.76(0.10)$ \\
\hline
\end{tabular}

This article is protected by copyright. All rights reserved. 


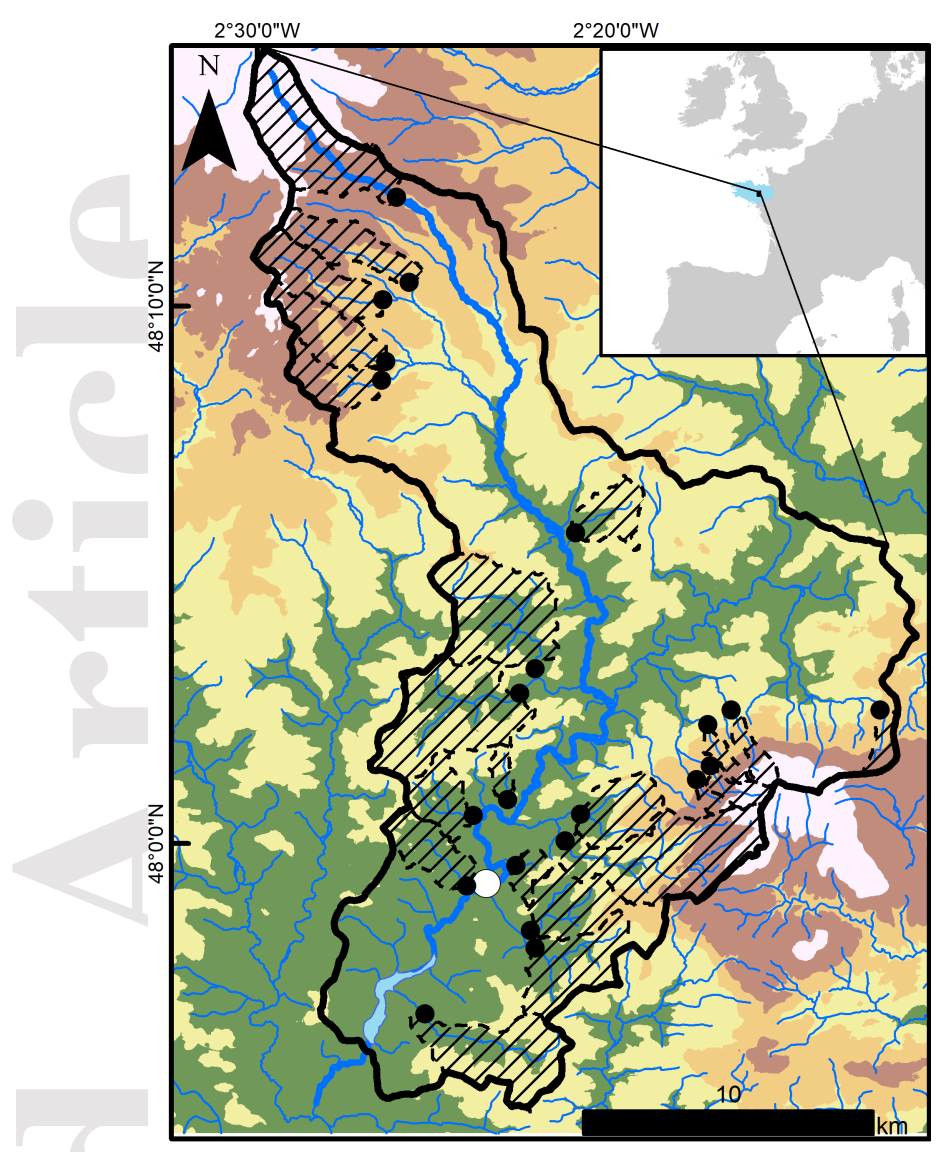

- Monitored subcatchment outlet Elevation a.s.I. (m)

[D, Monitored subcatchment $\quad 21-80$

Discharge and quality monitoring $\square 80-110$

$\begin{array}{lr}\square \text { Catchment } & \square 110-150 \\ \sim \text { Main river } & 150-200 \\ \text { Hydrography } & 200-303\end{array}$

This article is protected by copyright. All rights reserved. 


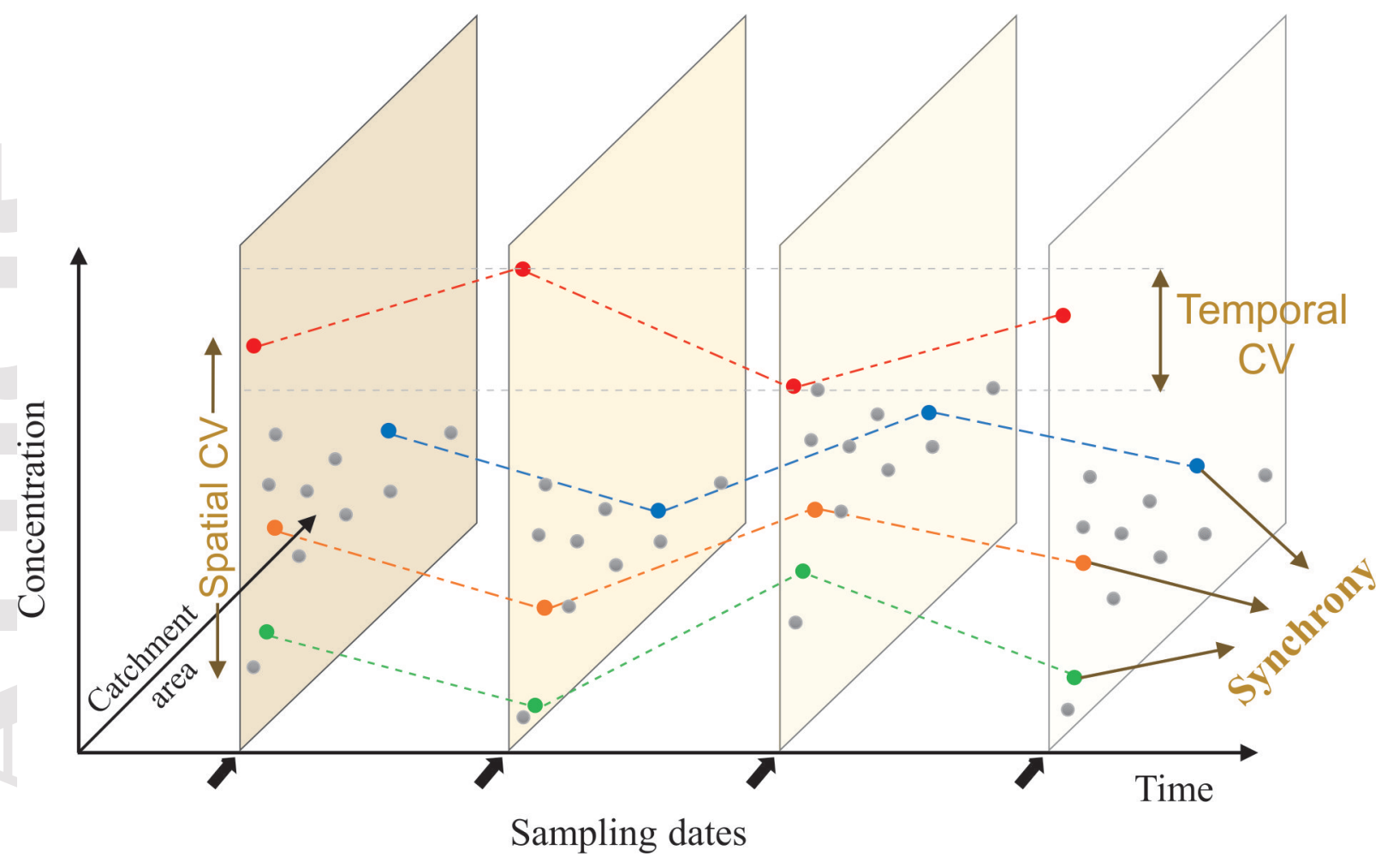

This article is protected by copyright. All rights reserved. 
(a)

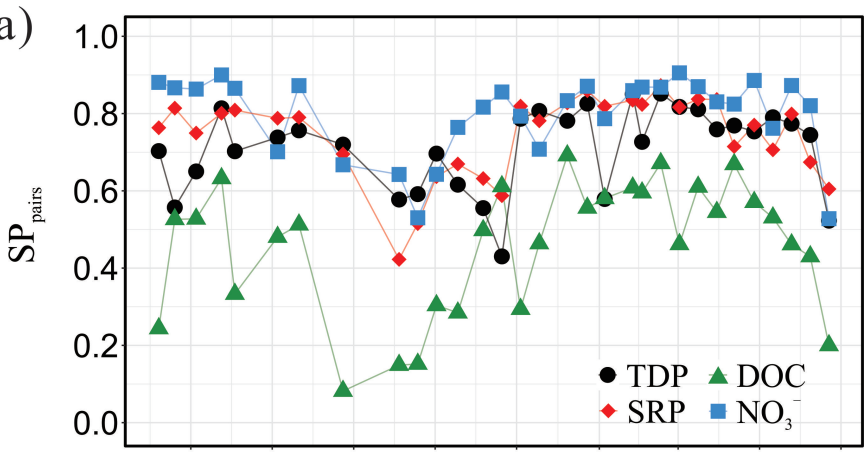

(b)

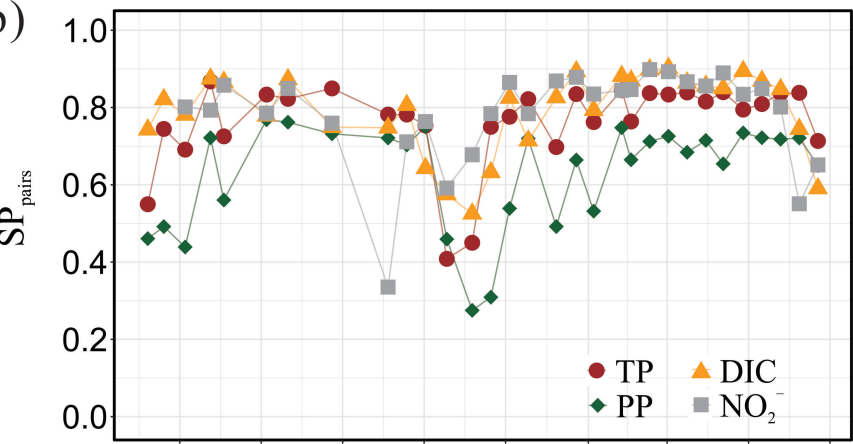

(c)

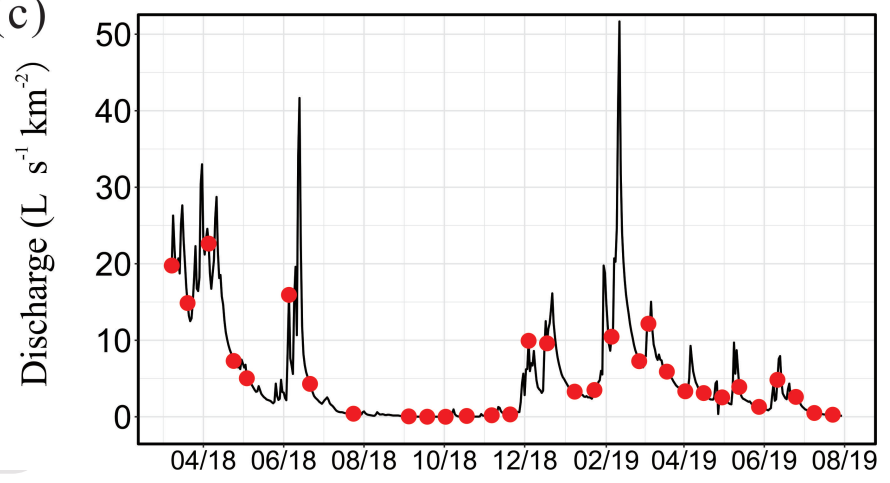

This article is protected by copyright. All rights reserved. 

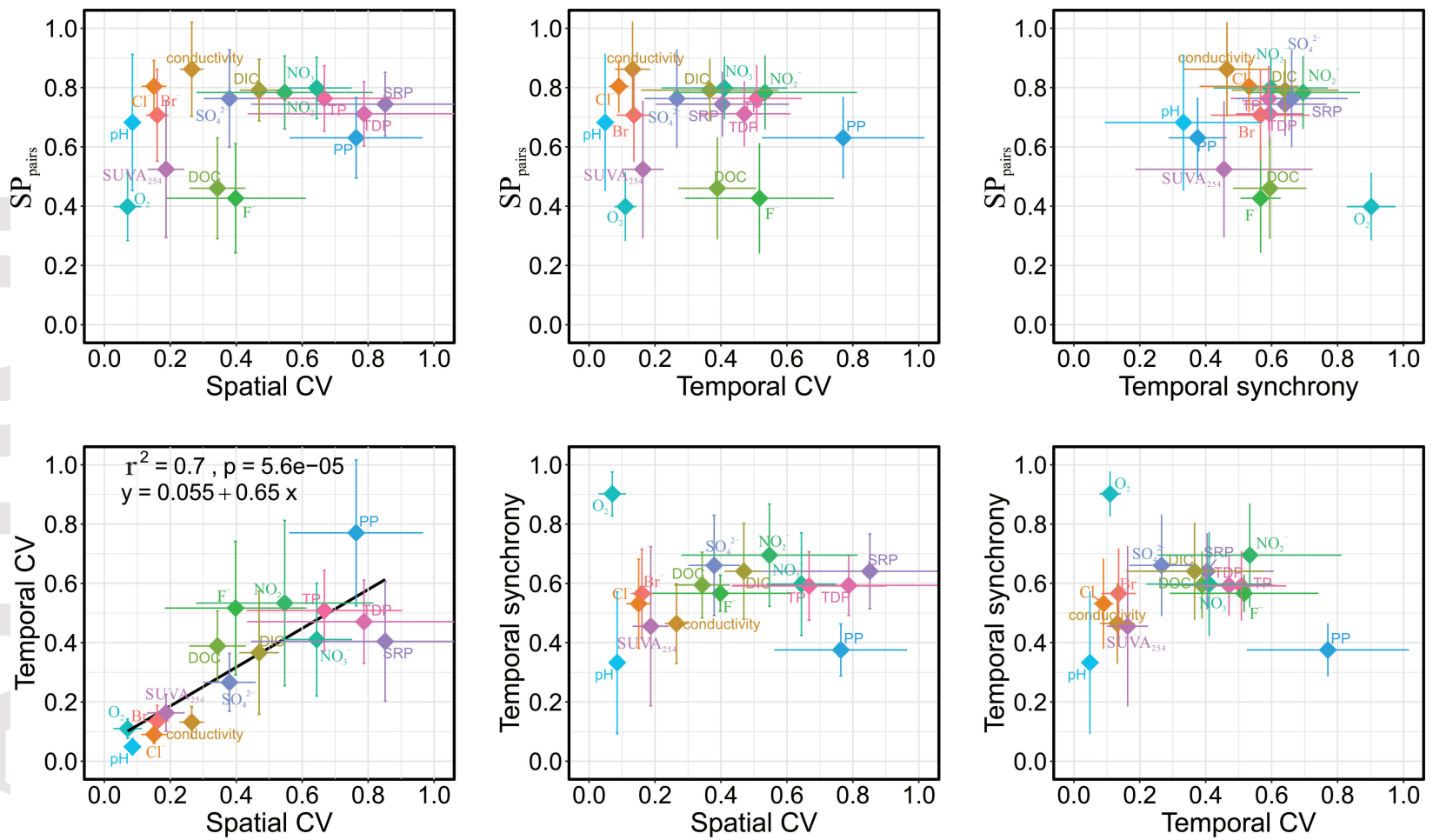

This article is protected by copyright. All rights reserved. 
(a)

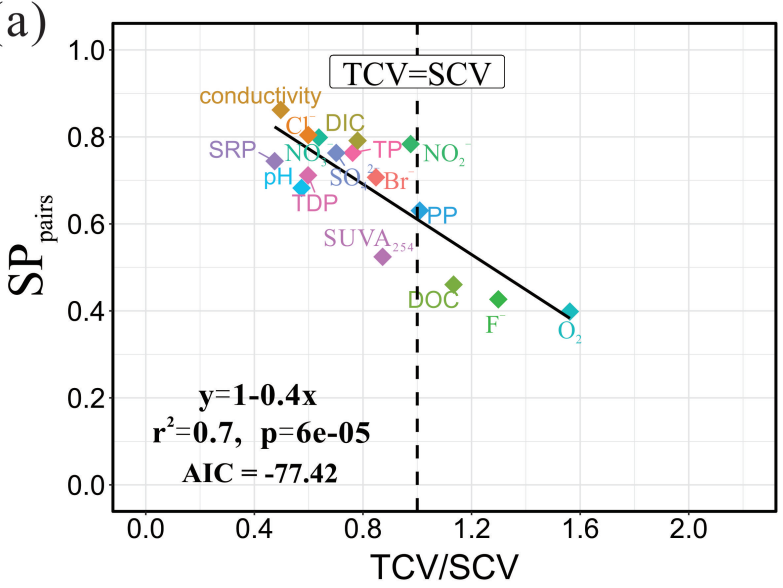

(b)

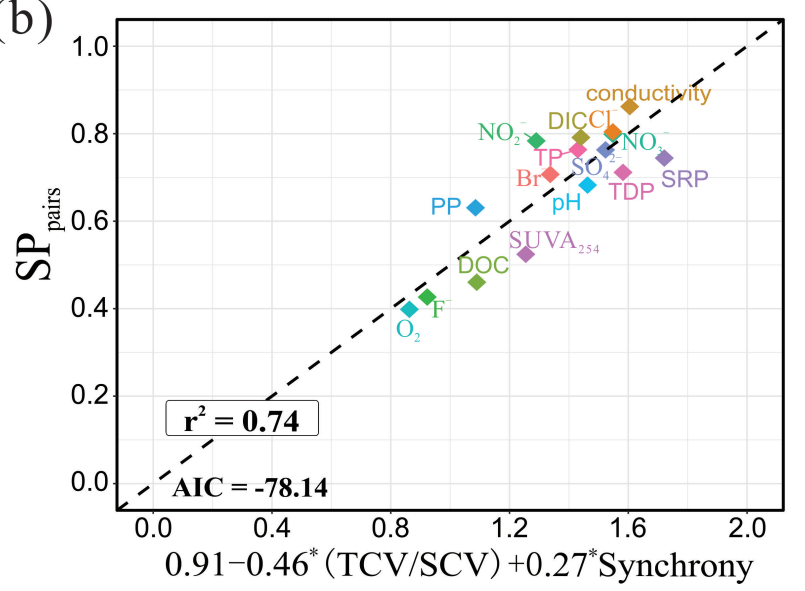

This article is protected by copyright. All rights reserved. 
(a)

(a)
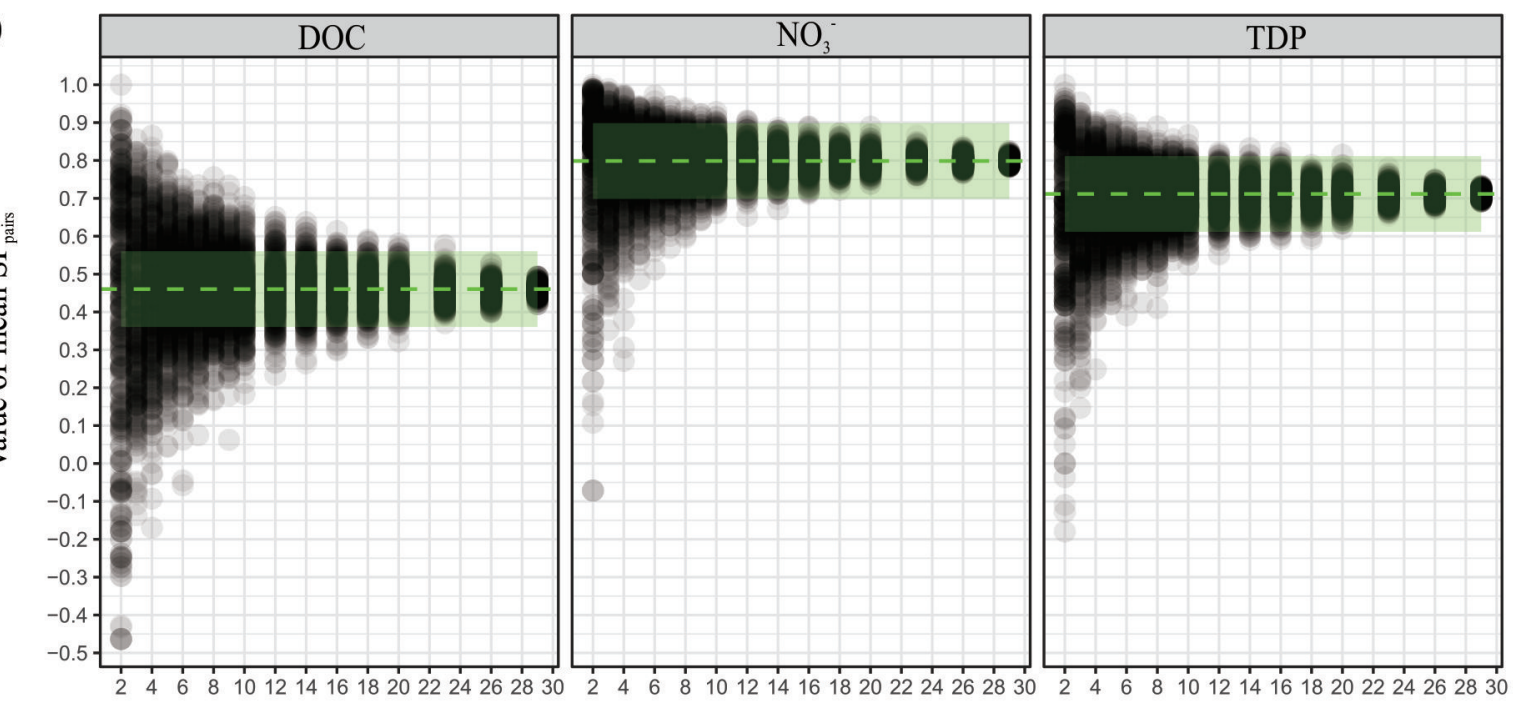

(b)
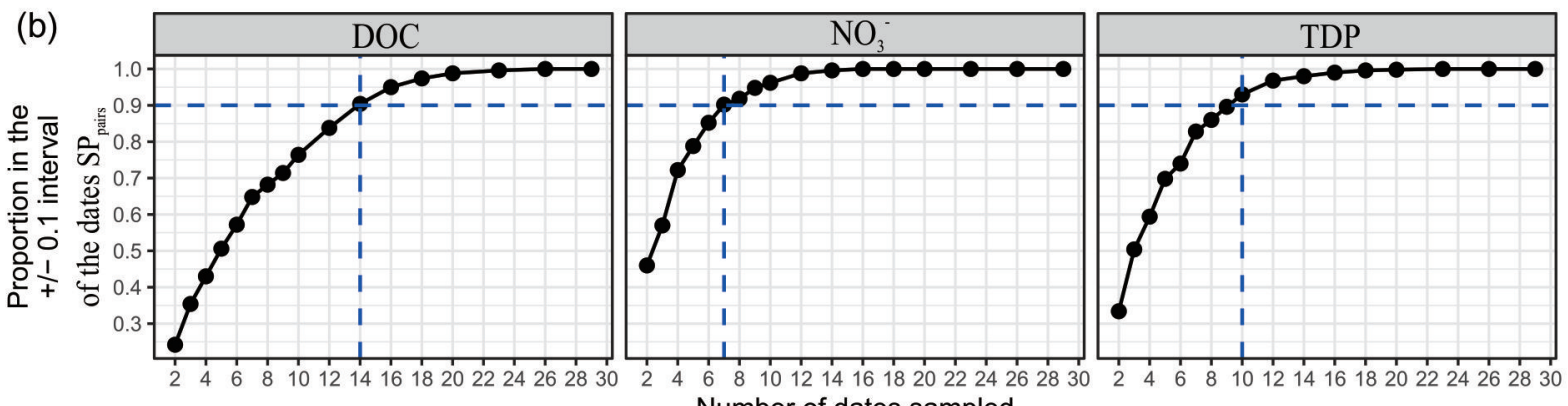
Number of dates sampled 